$$
\begin{gathered}
\text { thejournal } \\
\text { of a mish } \\
\text { and } \\
\text { pl ain an abaptist } \\
\text { st udies }
\end{gathered}
$$

Spring 201

Volume 5, Issue 1 


\title{
The Journal of Amish and Plain Anabaptist Studies
}

\author{
Editor \& Co-Founder \\ Cory Anderson, Truman State University \\ Assistant Editor \& Co-Founder \\ Joseph F. Donnermeyer, The Ohio State University
}

Editorial Board

\author{
Mark Louden \\ Univ. of Wisconsin-Madison
}

\author{
Denise Reiling \\ Eastern Michigan Univ. \\ Steven Reschly \\ Truman State Univ.
}

The Journal of Amish and Plain Anabaptist Studies welcomes manuscripts, both theoretical and empirical, about plain Anabaptist groups, including Amish, Apostolic Christian, Brethren, Bruderhof, Hutterite, Russian Mennonite, Swiss Mennonite, and related movements. Under normal circumstances, the manuscript should be no more than 10,000 words, including tables, figures, endnotes, and references. The journal further seeks to include the empirical research of members from plain Anabaptist churches, who are invited to submit manuscripts for special consideration. Citation and referencing style is similar to the American Journal of Sociology (http://www.jstor.org/page/journal/amerjsoci/instruct.html).

Book:

Schreiber, William. 1962. Our Amish Neighbors. Chicago, IL: University of Chicago Press.

Article:

Kusnetzky, Lara, Jeffrey Longhofer, Jerry Floersch, and Kristine Latta. 1995. "In Search of the Climax Community: Sustainability and the Old Order Amish.” Culture and Agriculture (50):12-14.

Chapter from an edited volume:

Enninger, Werner. 1988. "Coping with Modernity: Instrumentally and Symbolically, with a Glimpse at the Old Order Amish.” Pp. 16-51 in Internal and External Perspectives on Amish and Mennonite Life 3, edited by Werner Enninger, Joachim Raith, and Karl-Heinz Wandt. Essen, Germany: Unipress.

Dissertation, thesis, or unpublished paper:

Friedrich, Lora. 2001. To Be or Not to Be: An Examination of Baptism into the Amish Church.

Doctoral dissertation in Rural Sociology. Columbus, $\mathrm{OH}$ : The Ohio State University.

Given the multi-disciplinary nature of our subject matter, authors may request to use the Chicago Manual of Style (Turbian) when the above style would force an unnatural fit. A bibliography is still required.

All manuscripts may be submitted by email (japas@beachyam.org) or postal mail: Cory Anderson, Department of Society and Environment, Truman State University, 100 E. Normal Ave., Kirksville, MO 63501. Publishers or authors wishing to submit a book for review should contact the editor.

The Ohio State University Knowledge Bank publishes the Journal of Amish and Plain Anabaptist Studies twice a year. The journal is available as open access (http://hdl.handle.net/1811/54889) and in print from Ridgeway Publishing for \$14.99 + \$4.95 shipping. You may request future copies to be mailed on an auto-ship basis: Ridgeway Publishing, 3129 Fruit Ave., Medina, NY 14103; 1-888-822-7894. 


\section{thejournal of amish and pl ain a n abapt ist st udies}

Volume 5, Issue 1 Spring 20I

Editor's note: This special volume dedicated to Amish studies consists of this and the next issue.

\section{cont ent s}

\section{Past Reflections and Future Directions in Amish Studies}

Special Volume, Issue 1 of 2

\section{Section 1: Critical Reflections in Amish Studies}

Editor's Introduction-

Seventy-Five Years of Amish Studies, 1942 to 2017: A Critical Review of

Scholarship Trends (with an Extensive Bibliography)

Cory Anderson

Paradigmatic Paradigm Problems: Theory Issues in Amish Studies

Steven Reschly

The Functionalist Problem in Kraybill's Riddle of Amish Culture

Michael S. Billig and Elam Zook

Section 2: Advances in Methods and Data

Reviving the Demographic Study of the Amish

Corey Colyer, Cory Anderson, Joseph Donnermeyer, Rachel Stein, and Samson Wasao

More than Forty Amish Affiliations? Charting the Fault Lines

Christopher Petrovich

\section{Book Review}

Horse-and-Buggy Genius: Listening to Mennonites Contest the Modern World-

Royden Loewen

Reviewed by Janelle Zimmerman 
